


\section{Air Quality in the Nordic Countries and Climate Changes in the Arctic}

LINKA

Bo Christiansen, Nis Jepsen, Rigel Kivi, Georg H. Hansen, Niels Larsen and Ulrik S. Korsholm

TemaNord 2017:542 


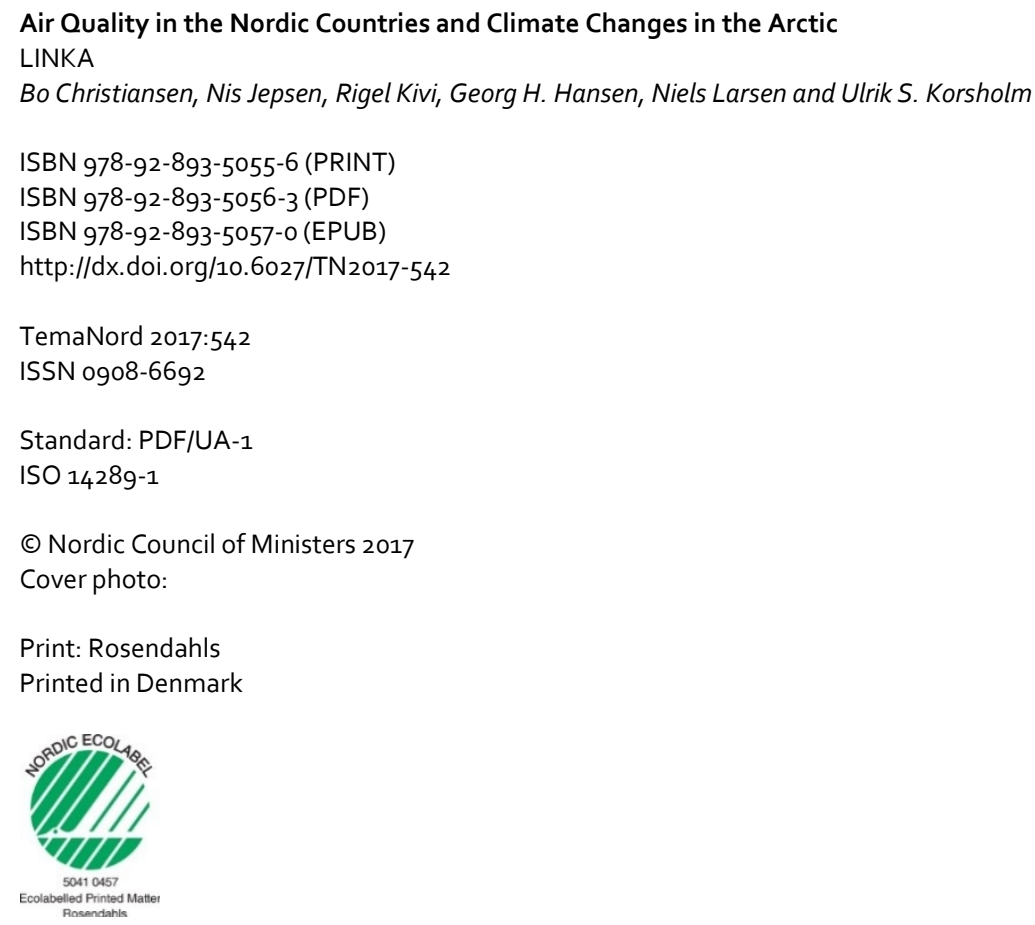

Although the Nordic Council of Ministers funded this publication, the contents do not necessarily reflect its views, policies or recommendations.

\section{Nordic co-operation}

Nordic co-operation is one of the world's most extensive forms of regional collaboration, involving Denmark, Finland, Iceland, Norway, Sweden, the Faroe Islands, Greenland, and Åland.

Nordic co-operation has firm traditions in politics, the economy, and culture. It plays an important role in European and international collaboration, and aims at creating a strong Nordic community in a strong Europe.

Nordic co-operation seeks to safeguard Nordic and regional interests and principles in the global community. Shared Nordic values help the region solidify its position as one of the world's most innovative and competitive. 


\section{Contents}

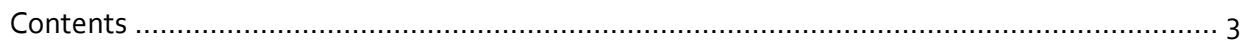

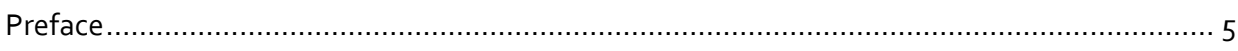

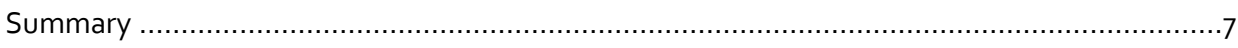

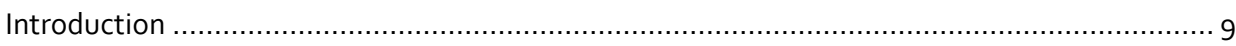

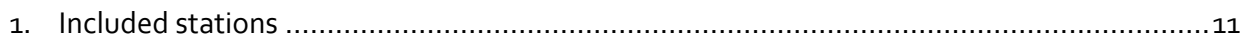

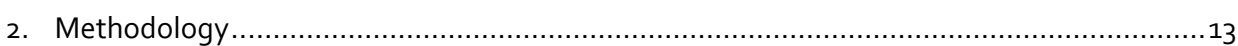

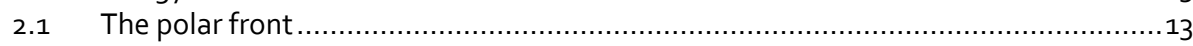

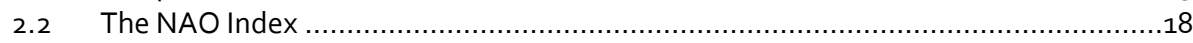

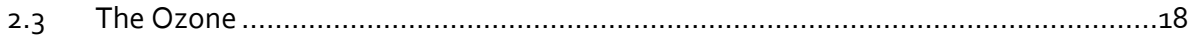

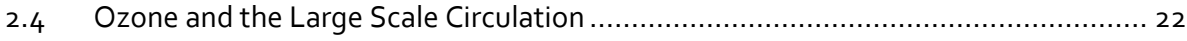

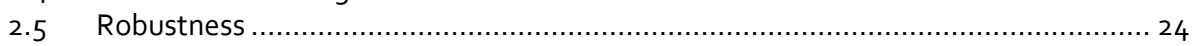

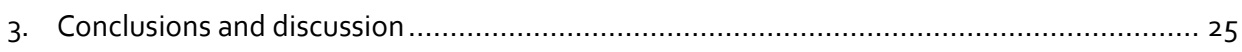

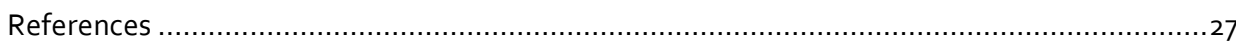

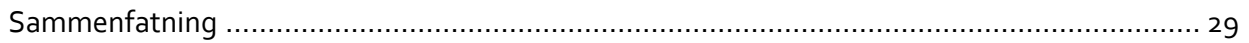





\section{Preface}

This report is prepared at the Danish Meteorological Institute (DMI) and describes the results of the Nordic Climate and Air Pollution Group (KOL, Klima- og Luftgruppen) project KOL-LINKA. The title of the project is "Luftkvalitet I Norden og Klimaændringer i Arktis" (LINKA), in English: "Air quality in the Nordic Contries and Climate Changes in the Arctic". The project contributes to increase the knowledge in the Nordic Countries about longterm surveillance of prioritized environment indicators/climate components.

Transport of short lived climate components (SLCPs), such as black carbon (BC), ozone and precursor gasses from the the Nordic countries into the Arctic is mainly dominated by largescale transport, ie transport governed by the polar front and the North Atlantic Oscillation (NAO). In the wintermonths - when the polar front is stretching far south - Nordic and European areas containing SLCP's are contained within the polar front, and consequently direct transport into the Arctic is possible.

To achieve synergy between the regulation of air pollutants in the Nordic Countries and the regulation of SLCPs in the Arctic it is necessary to know the influence of the polar front - and hence long tranported gasses - on the chemistry in the Arctic troposphere as well as the future development of the polar front seasonal extent.

DMI, FMI (Finnish Meteorological Institute) and NILU (Norwegian Institute for Air Research) have since the early 199oies been monitoring ozone in the Arctic stratosphere using ozonesondes, the purpose of which being primarily reporting the stratospheric ozone content according to the Vienna Convention. However, these profile measurements also include measurement data in the troposphere. In this project we will try to couple the tropospheric ozone soundings from different stations with the extent of the polar front. The achieved synergy may bring new knowledge about the polar front influence on transport of precursor gasses from the Nordic countries and elsewhere to the Arctic, as well as on the development in a future climate and is based on the NMR (Nordic Council of Ministers) project KOL 1402 "Time Series Analysis of Arctic tropospheric ozone as a short-lived climate forcer" (Christiansen et al., 2015) the main purpose of which was analyzing trends in the observations of arctic tropospheric ozone at a number of individual stations.

To achieve synergy between the regulation of airpollutants in the Nordic Countries as well as of SLCPs in the Arctic, knowledge about the importance of precursor gas transport into the Arctic is necessary. The SLCP effect on ozone formation should be compared to local effects, such as mixing of stratospheric ozone into the upper troposphere. In particular it is relevant - in a policy context - to evaluate how these relationships may change in a future climate.

The fulfilment of the purpose of the project will be achieved via 2 milestones: an observation based investigation of the connection between the polar front extent and 
the tropospheric ozone levels in the Arctic; and examination of how climate changes affect the seasonal spread of the polar front.

The first milestone is reached by investigating the statistical correlation between tropospheric ozone levels and the area included by the polar front. Such an analysis shows the importance of long transported gasses on the ozone levels. The results from the second milestone evaluates the future changes in the polar front extent. The results achieved in milestone one determines whether it is worthwhile to investigate milestone two. If so, this could be the subject in a follow-up application.

The implementation of this project fits well into the Nordic Environment Program 2013-2018 as it contributes to increasing the knowledge in the Nordic countries on longterm surveillance of prioritized environment indicators/climate components. This work is in part a continuation of the NMR KOL 1402, a work incorporated in the "AMAP Assessment 2015: Black carbon and ozone as Arctic climate forcers" (Law et al., 2015).

The partners in the project are the Finnish Meteorological Instute (represented by Rigel Kivi), NILU (Norwegian Institute for Air Research, represented by Georg H. Hansen) and the Danish Meteorological Institute (represented by Bo Christiansen, Niels Larsen, Ulrik Smith Korsholm and Nis Jepsen). The work has been done in 2015-16 and has been financially supported by the Nordic Council of Ministers. Profile data from the following stations has been used: Eureka, Sodankylä, Ny Ålesund and Scoresbysund (Ittoqqortoormiit). We thank the Danish Environmental Protection Agency and the Danish Energy Agency for financial support of the DMI ozonesoundings in Greenland over the years. Thanks to David Tarasick (Eureka) and Peter von der Gathen (Ny Ålesund) for the use of their ozonesounding data. Data from the other stations under consideration were available within the project. 


\section{Summary}

An enhanced activity in the Arctic is to be expected in the near future with contributions from increasing shipping acticity and an increased search for sub-seafloor occurrences of especially oil and gas. On land an - not least in Greenland - enhanced activity is to be expected by the extraction of industrial minerals. This activity will lead to a larger burning of fossil fuels and hence also an increased occurrence of shortlived climate components. An increased occurrence that may only be regulated politically.

One of these climate components is trophospheric ozone because it may be formed as a byproduct when combusting fossile fuels. In contrast to stratospheric ozone (the socalled ozone layer, cf below) tropospheric ozone is an unwanted constituent. There are a number of reasons for this. Although tropospheric ozone - like stratospheric ozone - absorbs especially the shortwaved part of the ultraviolet radiation, it also has a number of poisoneous side effects due to its very reactive nature. In this respect it may affect living tissue, such as the lungs in mammals, and also respiratory plant tissue.

The tropospheric ozone data used in this investigation may be seen as a "byproduct" from the ozone soundings. These measurements were originally initiated as an investigation of the stratospheric ozone as a fulfillment of the Montreal Protocol to monitor the ozone layer. In this respect the term "ozone layer" always refer to the stratospheric ozone, ie. ozone in the atmosphere at $25-40 \mathrm{~km}$ altitude. These measurements began in the late 1980ies or early 199oies for most stations. The ozone sounding itself is done lifting the sounding equipment with a balloon until it bursts, usually to around $35 \mathrm{~km}$ of altitude. The measurement of ozone is done during ascent only.

So even though the main purpose of the ozone soundings was the investigation of the stratosphere, the same data may now be used to establish a baseline for the trophospheric ozone as it has been for the last 30 years. And hopefully the data series will continue to grow in the years to come so that we are still able to monitor and detect changes of the ozone concentrations in the stratosphere as well as in the troposphere.

The amount of tropospheric ozone at a given location is assumed to be regulated in three ways: by local formation of precursors, by supply of precursors from other locations, and by folding of the stratosphere into the troposphere. The precursors whether locally formed or supplied from elsewhere - may react and form tropospheric ozone. The folding of the stratosphere will directly inject ozone into the upper troposphere. From a policymaker point of view only the locally formed and supplied precursors may be regulated. Ozone precursors come from human activity, such as by burning of fuel, as well as from natural sources, such as forest fires. The stratospheric folding is a process inherent in the atmospheric dynamics.

As part of this project we have investigated the link between the polar front and the arctic tropospheric ozone. The polar front is a circumpolar boundary that separates warm air-masses in the South from colder air-masses in the polar region. 
It was found that the polar front area shows a decreasing trend, possibly due to the general warming of the trophosphere.

Another issue of investigation is the link between the polar front and indices of the large scale circulation, such as the North Atlantic Oscillation (NAO). Furthermore, the polar front area correlates strongly and negatively with the NAO.

Using the homogenized ozone sonde series from the former $\mathrm{KOL}$ report (Christiansen et al., 2015) the anomalies have been calculated as the residual after removal of the secular trend and the annual cycle. Using a kernel smoother (Hastie et al., 2009) the anomalies have been interpolated to daily values.

In this way a weak but significant correlation was found between the stations in question.

Also it was found that the NAO correlates negatively with ozone anomalies for all four stations albeit the correlations are weak.

These results together with the observation that the ozone-anomalies have a short decorrelation time, indicates that most of the variability in the anomalies should be found in local conditions. 


\section{Introduction}

As part of the fulfilment of the Vienna Convention on protection of the ozone layer, a number of locations with long ( $>20$ years) time series of atmospheric profile measurements exist in the Arctic. These long time series constitute a unique data set. The measured quantities are pressure, temperature, humidity, wind direction and speed as well as ozone and internal ozonesonde temperature. The measurement itself is typically being done weekly. The Vienna Convention only deals with the monitoring of stratospheric ozone. However, the time series also contains valuable measurements of trophospheric ozone as all measurements start at the surface when the balloon is released. These ozone soundings constitute the longest time series of ozone measurements in the free trophosphere.

Tropospheric ozone is a shortlived climate forcer (SLCF) or shortlived climate component (SLCC). The purpose of the project is to investigate the correlation between the polar front and the level of locally existent trophospheric ozone. Originally the time series used in the KOL 1402 project was included in this study. However, as the lifetime of trophospheric ozone is rather short, usually a few weeks, and as the typical ozone profile measurement frequency is once a week, only the stations with the best data coverage are used. This includes the time series from Sodankylä in Finland, Ny Ålesund in Spitsbergen, Scoresbysund in East Greenland and Eureka (Canada).

Due to the diminishing amount of ice in the Arctic the activity - none the less at sea - has increased in recent years. This encompasses an increased burning of fossile fuels and hence also an increased release of NOx-gasses and VOX (volatile organic halogen) which inevitably may lead to an increased content of tropospheric ozone.

The anthropogenic pollution from the Northern Hemisphere is the dominant source of $\mathrm{O}_{3}$ and $\mathrm{HNO}_{3}$ in the Arctic at pressures greater than $400 \mathrm{hPa}$, and the stratospheric influence is the principal contribution at pressures below $400 \mathrm{hPa}$ (Wespes et al., 2012). The anthropogenic sources may either be formed in situ or transported to the site of reaction. Nitrogen oxides are considered especially important in this respect. Besides being formed by anthropogenic activities, nitrogen oxides may also be formed in lightning processes (Cairo et al., 2010). The chemical ozone production takes place in the troposphere only, while the chemical ozone destruction mechanism may be the same as in the stratospheric vortex (Larsen et al., 1994). Aerosols act as catalysts upon which the breakdown takes place. In the stratosphere these aerosols may be nitric acid or ice particles (Larsen et al., 1996). The dry deposition rate has been calculated to be $0.1-0.5$ $\mathrm{cm} / \mathrm{s}$ (Pio et al., 1996) depending on time of year and time of day. These values were estimated for Southern Europe. Here, the concept of the deposition being composed of additive contributions of aerodynamic resistance, quasi-laminar boundary layer resistance and canopy resistance, is introduced. However, similar values have been 
obtained for Western Alaska, that is $0.12-0.24 \mathrm{~cm} / \mathrm{s}$ (Jacob et al., 2012). The average lifetime for tropospheric ozone is 19-33 days (IPPC, 2007).

The influx from the stratosphere may be caused by tropopause folding. This has been demonstrated using backwards trajectory calculation (Sørensen et al., 2000). Synoptic scale processes as represented by the $250 \mathrm{hPa}$ geopotential height have also been successfully linked to the recent ozone increases in the lowermost stratosphere (Harris et al., 2008). Another influx can be simple transport of low ozone air parcels. This has been demonstrated using NWP (Rasmussen et al., 1997).

We want to investigate the link between the polar front and the arctic ozone. The polar front is a circumpolar boundary that separates warm air-masses from the south from colder air-masses in the polar region. The polar front is usually characterized by sharp gradients in temperature and geopotential heights. The sharp gradient is the source of polar storms and the polar front corresponds to some degree with the storm tracks. The polar front can also be described as where the polar and the Ferrell cells meet. A working definition of the polar front is the $5,520 \mathrm{~m}$ isohypse of the $500 \mathrm{hPa}$ geopotential height. 


\section{Included stations}

We have previously - KOL report (Christiansen et al., 2015) and submitted paper (Christiansen et al., 2017) - homogenized and analyzed the ozone soundings from 9 Nordic stations. As part of this work we interpolated the homogenized series to standard pressure levels. The different stations have very different data coverage and for the present study we select the 4 stations with best coverage: Scoresbysund, Sodankylä, Ny Ålesund, and Eureka. For the same reasons we use the period 19932011. The included stations are listed in the following Table 1. These stations have all been submitting data to either the NILU and/or the NDACC database over the years.

The geographic distribution is as shown in Figure 1.

Table 1: Included stations sorted by Latitude

\begin{tabular}{lrr} 
Station Name & Latitude & Longitude \\
Eureka (CA) & $80.1^{\circ} \mathrm{N}$ & $86.4^{\circ} \mathrm{W}$ \\
Ny Ålesund (DE) & $78.9^{\circ} \mathrm{N}$ & $11.9^{\circ} \mathrm{E}$ \\
Scoresbysund (Ittoqqortoormiit) (DK) & $70.5^{\circ} \mathrm{N}$ & $22.0^{\circ} \mathrm{E}$ \\
Sodankylä (FI) & $67.4^{\circ} \mathrm{N}$ & $26.7^{\circ} \mathrm{W}$ \\
\hline
\end{tabular}

All the stations included are participating in the yearly Match Campaign run by AWI (Rex, 1993; von der Gathen et al., 1995). This means that in the wintertime, more ozonesondes than weekly may be released which of course improves the temporal data coverage. A description of the ozonesonde may be found on the Jülich website (Jülich, 2012).

Each recorded profile consists of a datafile that besides a header describing such details as instrumentation, serial number for included hardware etc., includes the following data fields: air pressure, altitude, temperature, humidity, wind speed and direction, ozone partial pressure, temperature inside ozone sonde and elapsed time since the launch. 
Figure 1: Geographic coverageof included stations, cf. Table 1. Stations are marked with an asterisk

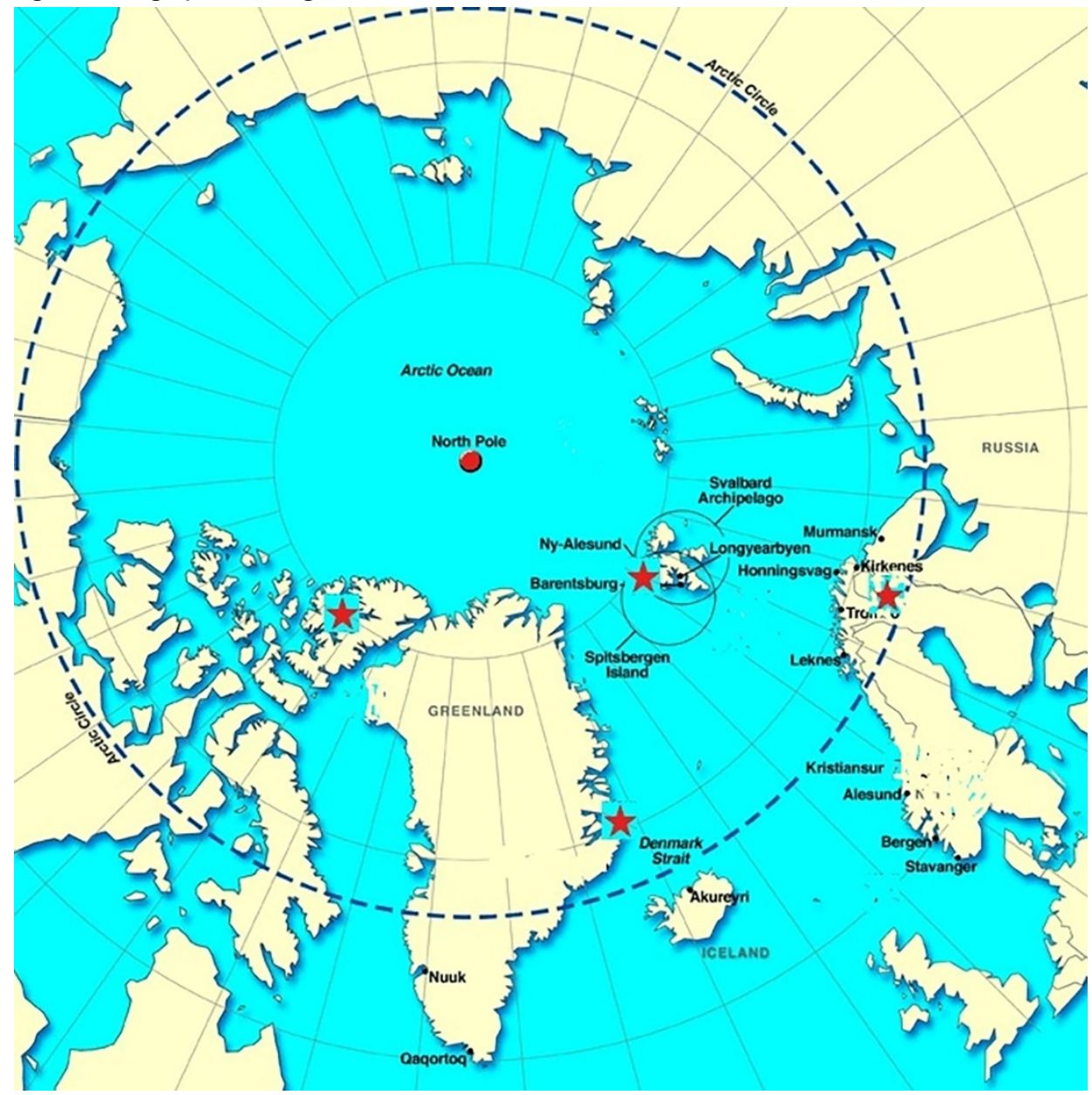




\section{Methodology}

\subsection{The polar front}

As part of this project we want to investigate the link between the polar front and the arctic ozone. The polar front is a circumpolar boundary that separates warm air-masses from the south from colder air-masses in the polar region. The polar front is usually characterized by sharp gradients in temperature and geopotential heights. The sharp gradient is the source of polar storms and the polar front corresponds to some degree with the storm tracks. Several ways exist to determine the position of the polar front. The geopotential height on the $300 \mathrm{hPa}$ level of the maximum wind speed is one way (Hudson et al., 2003). The polar front can also be described as where the polar cell and the Ferrell cell meet (Metoffice, 2016). A working definition - which we also will use of the polar front is the $5,520 \mathrm{~m}$ isohypse of the $500 \mathrm{hPa}$ geopotential height.

Figure 2: The Polar front for a winter day. In the first three panels the $500 \mathrm{hPa}$ heigths are shown. In the upper left panel the 5,520 isohypse is indicated by the dotted curve
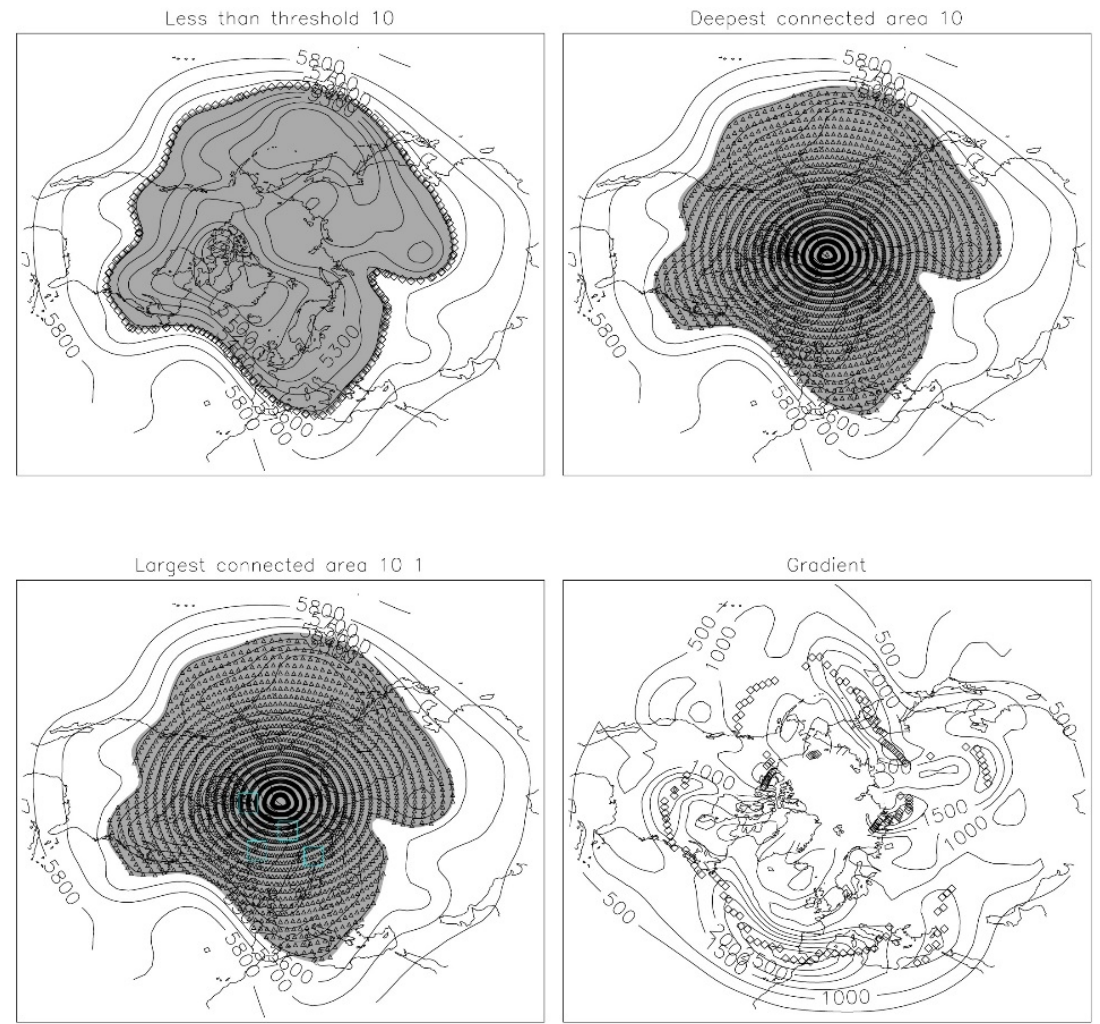

Note: The upper left and lower right panels show with dots the deepest and largest connected areas, respectively (in this case they coincide). The lower left panel shows the strength of gradient of the $500 \mathrm{hPa}$ heighs and (with dots) the attempt to identify the curve of maximum absolute gradient. 
Figure 2 shows the conditions of the $500 \mathrm{hPa}$ geopotential height for a typical winter day. Panel a shows both the polar front and the region behind the polar front (dark shaded). It is obvious that the polar front and the polar region are well-defined is this case: the 5,520 m isohypse forms a complete and unique closed curve. However, in summer the situation may be different, as shown in Figure 3. Here, the 5,520 m isohypse creates multiple islands. There are several ways to proceed in this situation. We can for the polar region choose all grid-points with geopotential height below $5,520 \mathrm{~m}$ (panel a). Alternatively, we can choose the largest island as the polar region (panel c) or we can use the island which includes the grid-point with the lowest value of $500 \mathrm{hPa}$ geopotential height (panel b). The areas of the polar region will differ according to which method is used with the largest area found for the first method and the smallest area for the third method.

Comparing the results of the different methods we find that they agree well in winter and only differ significantly in summer. As we are mainly interested in winter we will in the following use the first definition.

Figure 3: as Figure 2 but for a summer day
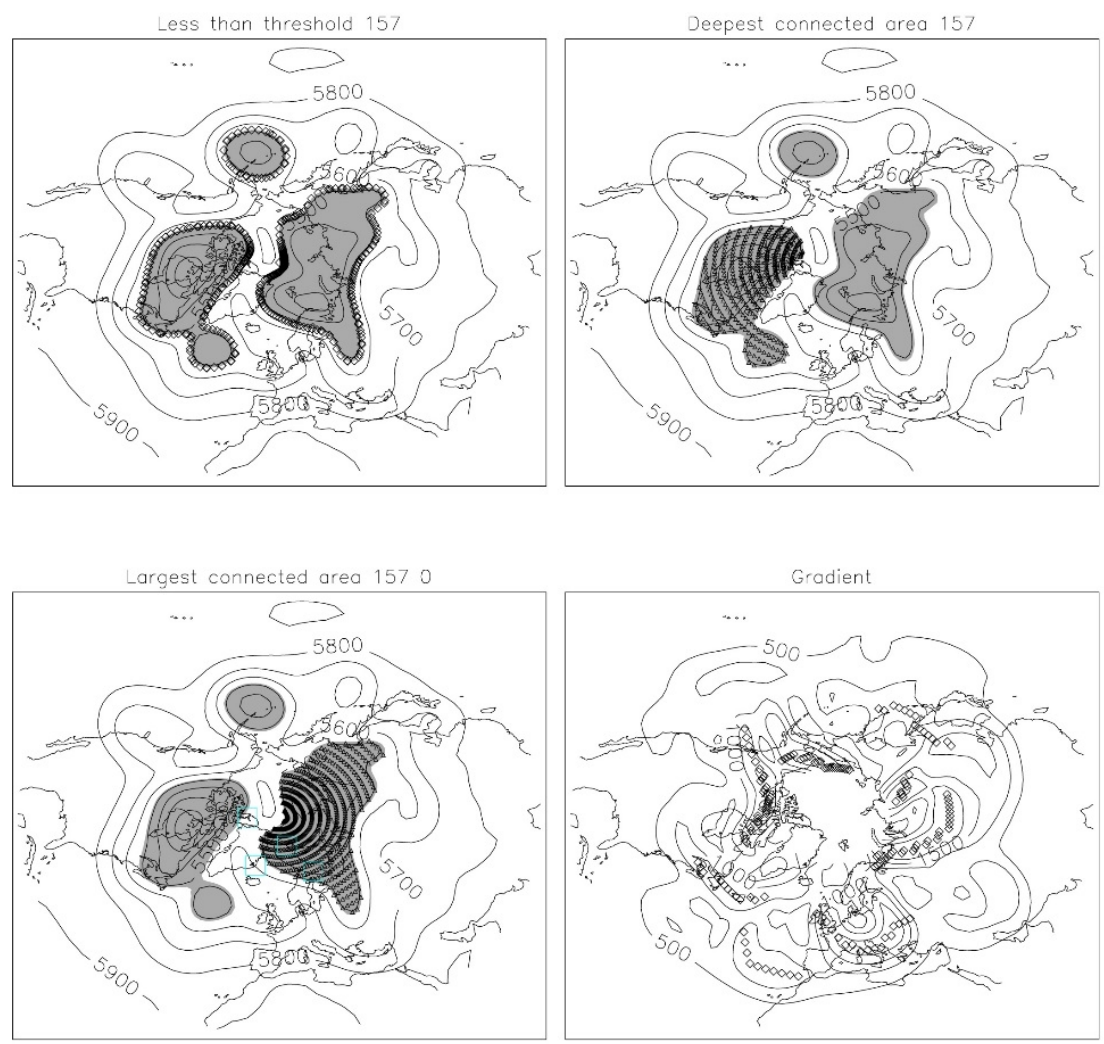

The last panels in Figure 2 and Figure 3 show the absolute value of the gradient of the $500 \mathrm{hPa}$ geopotential height. In winter strong gradients are found in the north Atlantic and the north Pacific corresponding to the 5,520 m isohypse. However, in other regions the gradient is less well confined. In summer the situation is even worse. Attempts to 
define the polar front by tracking the curve of strongest gradient have not resulted in a well-defined curve. However, when the well-defined curve of strongest gradient exists it usually coincides with the 5,520 $\mathrm{m}$ isohypse justifying the use of this approach.

We have calculated daily values of the area of the polar front from data from the NCEP (National Centers for Environmental prediction) reanalysis for the period 19582014. The timeseries (Figure 4, top panel) of the daily values is dominated by a strong annual cycle with almost vanishing values in some summers. The winter maxima show inter-annual variability, and a decreasing trend seems apparent. This lowfrequency variability will become clearer in the timeseries of winter averages (Figure 4, bottom left panel). It is obvious that the values in the first half of the period are larger than those in the last half and the change has a form between a sudden jump and a linear trend. We have confirmed that the trend is also present in data from the ERA reanalysis (ECMWF-Reanalysis, ECMWF being European Centre for MediumRange Weather forecasts) (1979-2008) and from this we conclude (Figure 4, bottom right panel) that it is not due to data-issues. We will come back to the reason for the change in the next section.

Figure 4: Left panels: polar front area calculated from the NCEP data. Top is daily values, bottom is winter means. Unit is area of polar cap north of $60 \mathrm{~N}$. Right panels: same calculations but now using ERA data
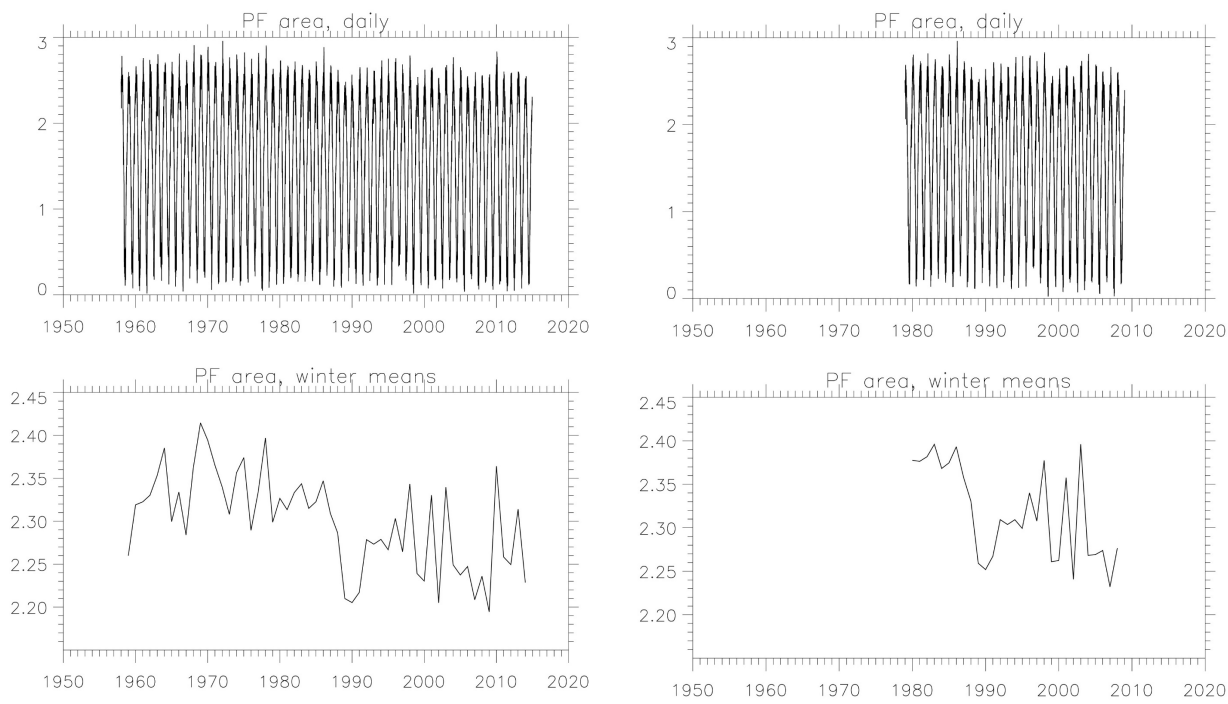

In Figure 5 the polar front area is calculated from NCEP data, this time with removal of congruent $\mathrm{NH}$ temperatures.

As we have seen, the position of the polar front is related to the storm tracks. It is therefore a reasonable assumption that the polar front area (i.e., the area of the region north of the polar front) is related to other indices of the large scale circulation. Figure 6 shows monthly winter (November-March) means for the polar front area, the NAO, the $\mathrm{NH}$ mean temperature, and the $\mathrm{NH}$ mean $500 \mathrm{hPa}$ height. It is quite obvious that these indices are strongly related. The correlation between the polar front area and the $\mathrm{NAO}$ is -0.56 . The negative value indicates that the polar front retreats when the NAO 
is negative and the Atlantic variability is dominated by blockings and reduced westerlies. Even for daily winter values the correlation between the NAO and the polarfront is as strong as -0.33 .

Figure 5: Polar front area calculated from the NCEP data: congruent NH mean temperature part removed
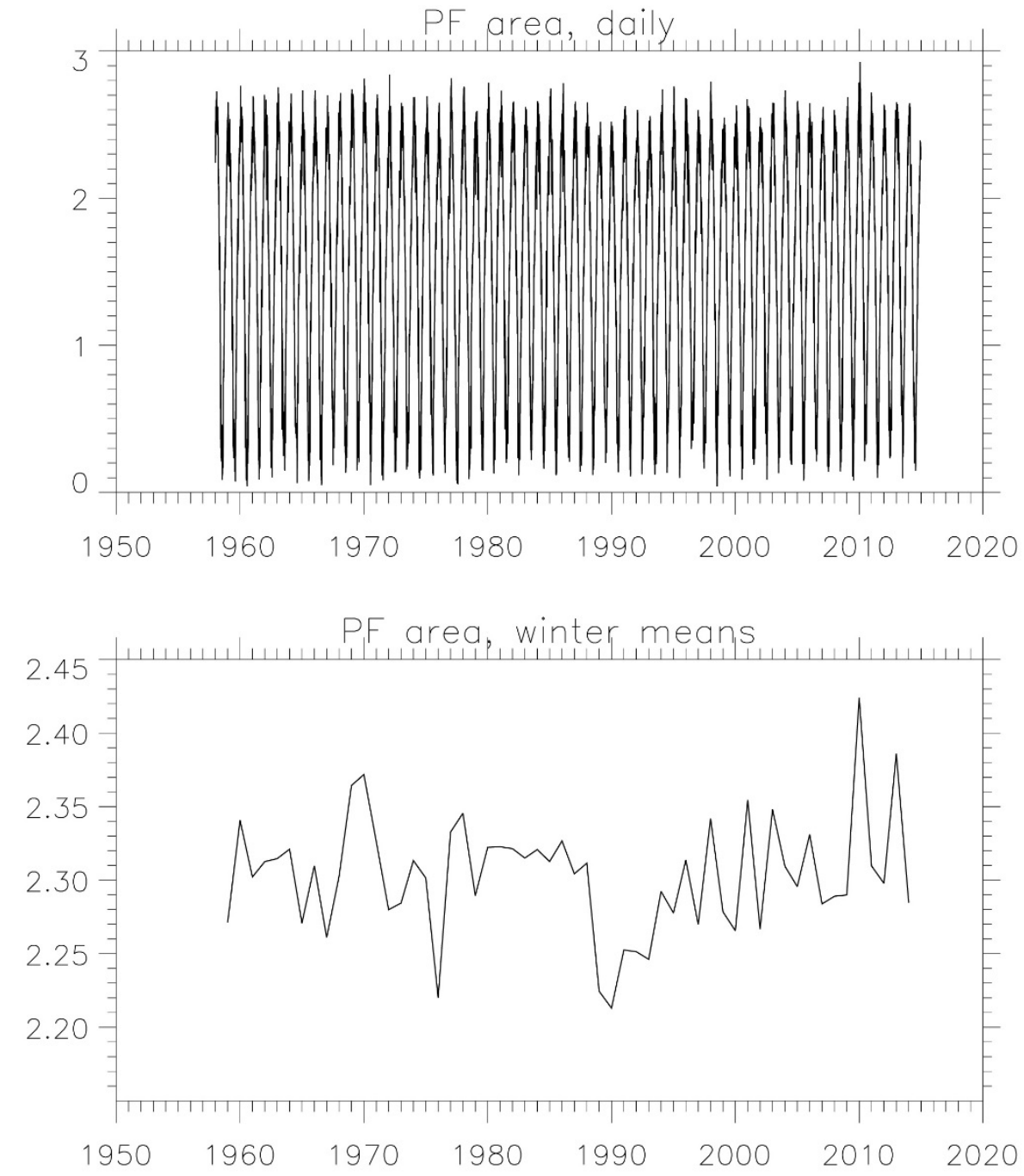

There is also a strong covariability between the polar front area and both the $\mathrm{NH}$ mean temperature and the $\mathrm{NH}$ mean $500 \mathrm{hPa}$ height. The correlations are -0.41 and -0.61 respectively. The negative correlations can be easily understood. When the $\mathrm{NH}$ surface and troposphere warms the whole $500 \mathrm{hPa}$ level is lifted - the correlation between these indices are 0.64 . As the height of the $500 \mathrm{hPa}$ layer increases from the polar region to the sub-tropics, this will force the $5,520 \mathrm{~m}$ isohypse to the north resulting in a smaller polar front area. 
Figure 6: Monthly values of polar front area, NAO, NH mean temperature, and $\mathrm{NH}$ mean $500 \mathrm{hPa}$ heights
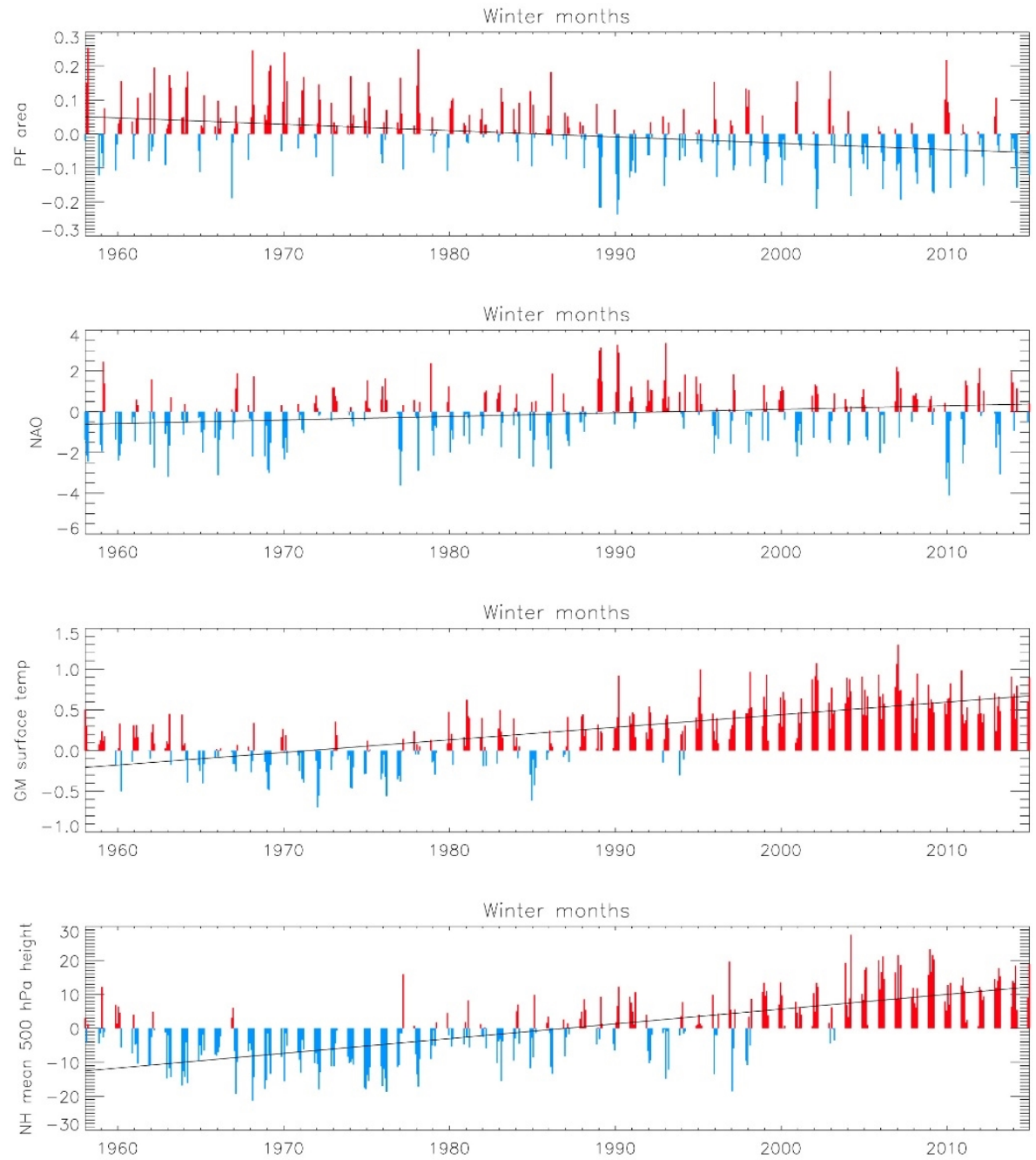

We note that the signs of the correlations are also reflected in the trends. While there is a negative trend in the polar front area there are positive trends in the NAO, the surface temperature, and the mean $500 \mathrm{hPa}$ height. This suggests that the trend in the polar front area is mainly a simple consequence of global warming and not related to dynamical changes. To confirm this mechanism we have subtracted from the $500 \mathrm{hPa}$ layer (for each grid-point) the part that is congruent to the $\mathrm{NH}$ mean $500 \mathrm{hPa}$ level. The polar front area now calculated from this field (Figure 6) does not show the decrease which is a clear sign that the trend is a simple consequence of global warming. 


\subsection{The NAO Index}

$\mathrm{NH}$ mean surface temperatures are from HadCRUT4 (MetOffice, 2016). The NAO index was downloaded from ftp://ftp.cpc.ncep.noaa.gov/ and is based on the leading EOF of the $1,000 \mathrm{hPa}$ geopotential height. The statistical significance is calculated by a MonteCarlo approach taking serial correlations into account. The kernel smoother basically works the following way: for an input signal $X(s)$ the output $Y(t)$ may be described as:

$$
Y(t)=\int K(t, s) X(s) d s
$$

where $\mathrm{K}(\mathrm{t}, \mathrm{s})$ is the kernel (Chung, 2012). In this case a gaussian kernel was used.

\subsection{The Ozone}

The data from the selected stations are shown in Figure 7 as a function of time and vertical level, and in Figure 8 as time-series for the lowest level (9oo hPa). To study possible changes we applied a model which included both low-frequency variability in form of a polynomial, an annual cycle with harmonics and the possibility for lowfrequency variability in seasonal amplitude. Because of irregularity of the data, the fitting of the parameters were performed with a Bayesian approach not only giving the posterior mean values but also $95 \%$ credible intervals. For all stations we found a clear annual cycle but only small temporal changes in form of polynomial trends or changes in the annual amplitude or timing.

Figure 7: Ozone partial pressure $(\mathrm{mPa})$ as a function of time and pressure for the 4 stations

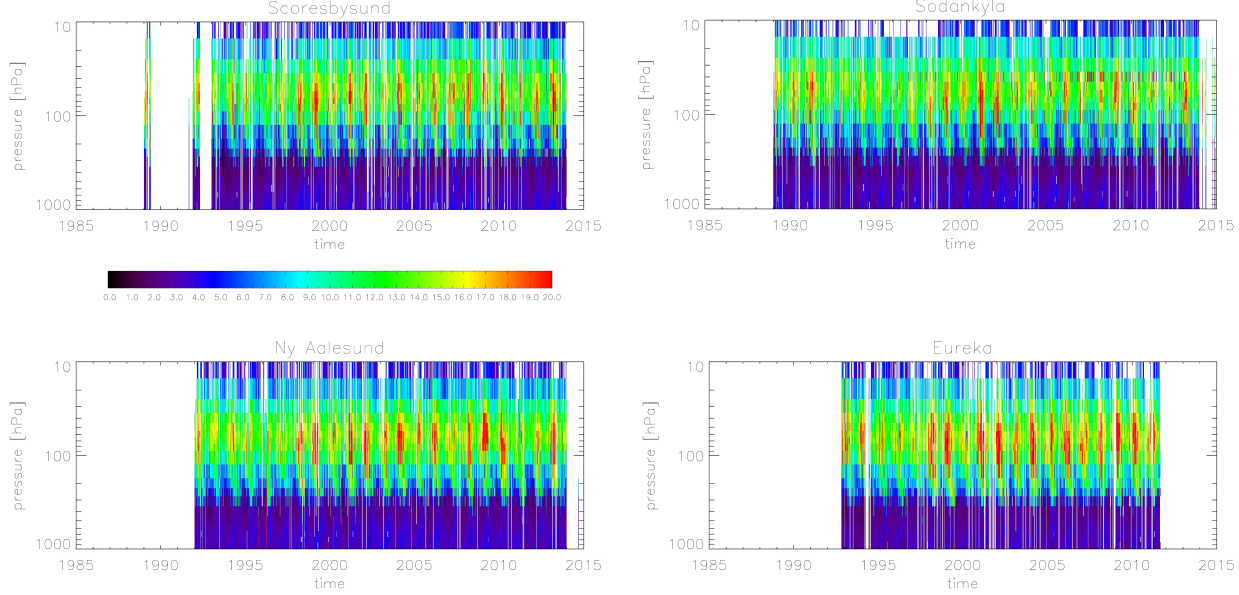

Note: For each station and for each ozonesounding the ozone is interpolated to the following pressure levels $900,800, \ldots 300,250, \ldots 100,80,70, \ldots 10$. 
Figure 8: Ozone partial pressure $(\mathrm{mPa})$ at lowest level $(900 \mathrm{hPa})$. The full curve is the fit including polynomial trend and annual cycle
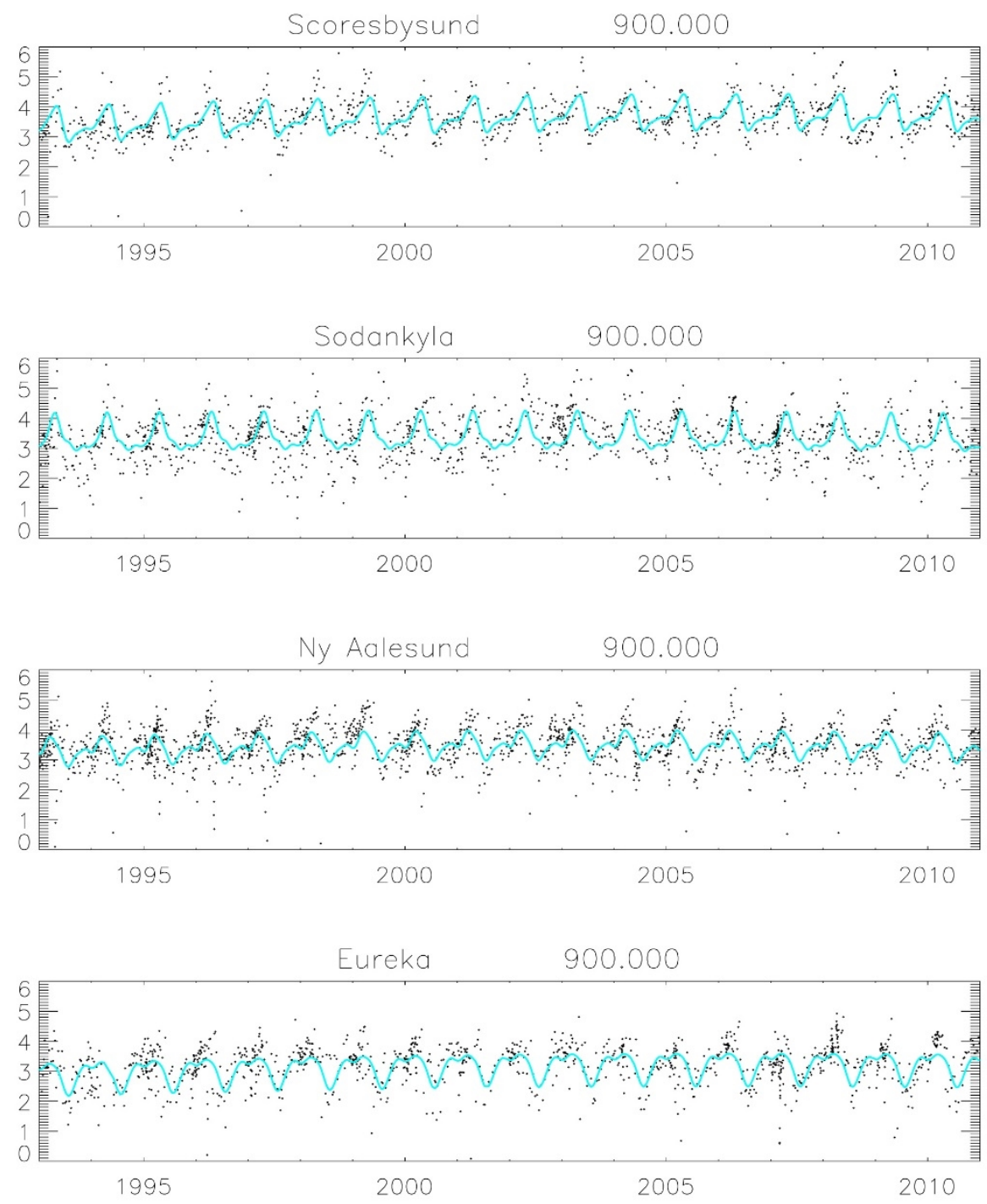

In this paper we are interested in dynamical changes in the ozone. We therefore for each pressure level calculate the anomalies as the difference between the observed ozone and the best fit of a model with a polynomial part and an annual cycle. We here use a 3 rd order polynomial and include 4 harmonics in the annual cycle. These fits are shown by the coloured curves in Figure 8. The resulting anomalies - shown in Figure 9 - still have missing values and in order to analyze correlations between different stations we interpolate to daily values using the kernel smoother (Chung, 2012). The kernel smoother also allows us to select the degree of smoothing. These smoothed anomalies are shown in Figure $g$ as the colored curves. Here the smoothing is chosen with a width of about a week which is also the average sampling period. Focusing on 
the raw data it is obvious that there is only little temporal structure; ozone changes come and go on a short time-scale. There is also only little apparent connection between the ozone anomalies at different stations.

Figure 9: Ozone anomalies at lowest level ( $900 \mathrm{hPa}$ ). Dots are the raw anomalies, the full curve is the interpolated and smoothed anomalies
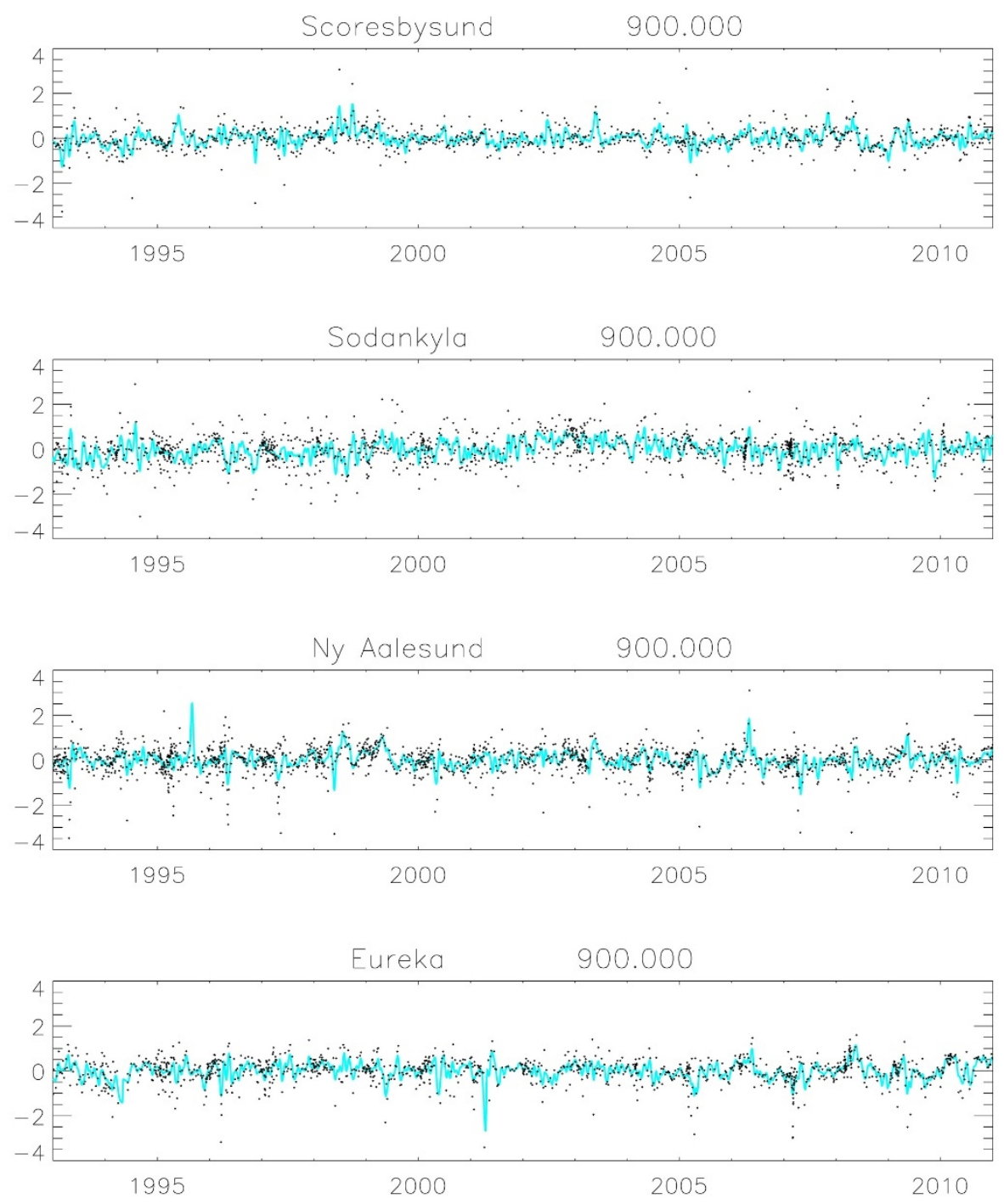

Figure 10 shows for each station the correlations between ozone at $900 \mathrm{hPa}$ with ozone at all other levels. Filled symbols indicate correlations that are significant at the $5 \%$ level according to a Monte Carlo test. We find that there is a strong correlation between the ozone anomalies in the lower troposphere. We also find that ozone near the surface only correlates weakly with ozone above $500 \mathrm{hPa}$. 
Figure 10: The correlations between the ozone at different vertical levels for the 4 stations. Filled symbols indicate significant correlations
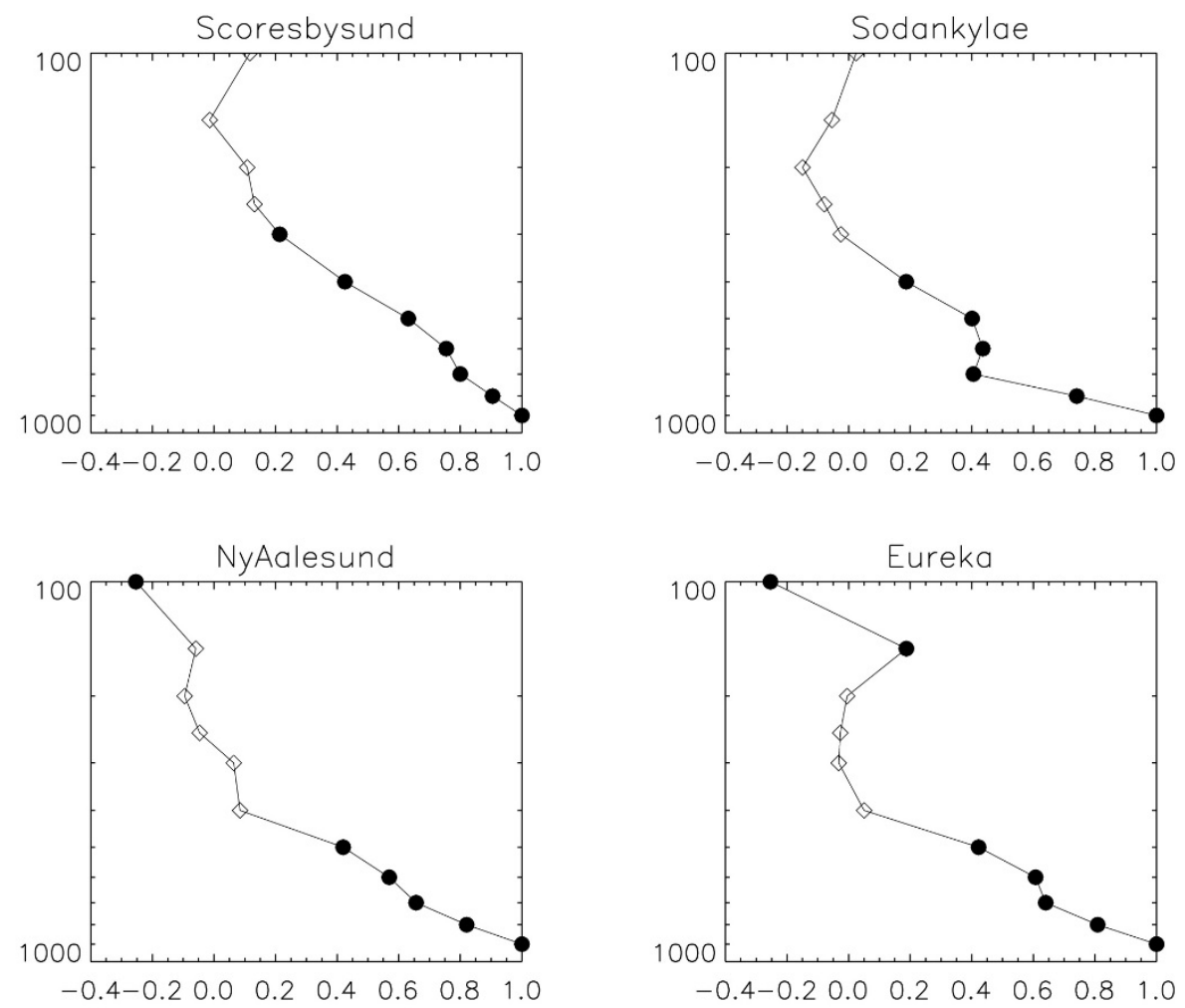

Figure 11 shows the correlations between ozone anomalies at a given layer but at different stations. The results are quite erratic but at least there seems to be agreement about a weak but positive and significant correlation in the lowest layers. The correlation at $900 \mathrm{hPa}$ varies between 0.12 and 0.36 with the weakest correlation between Sodankylä and Eureka and the strongest between Scoresbysund and Ny Ålesund. 
Figure 11: The correlations between the ozone at different stations but at the same vertical level. Filled symbols indicate significant correlations
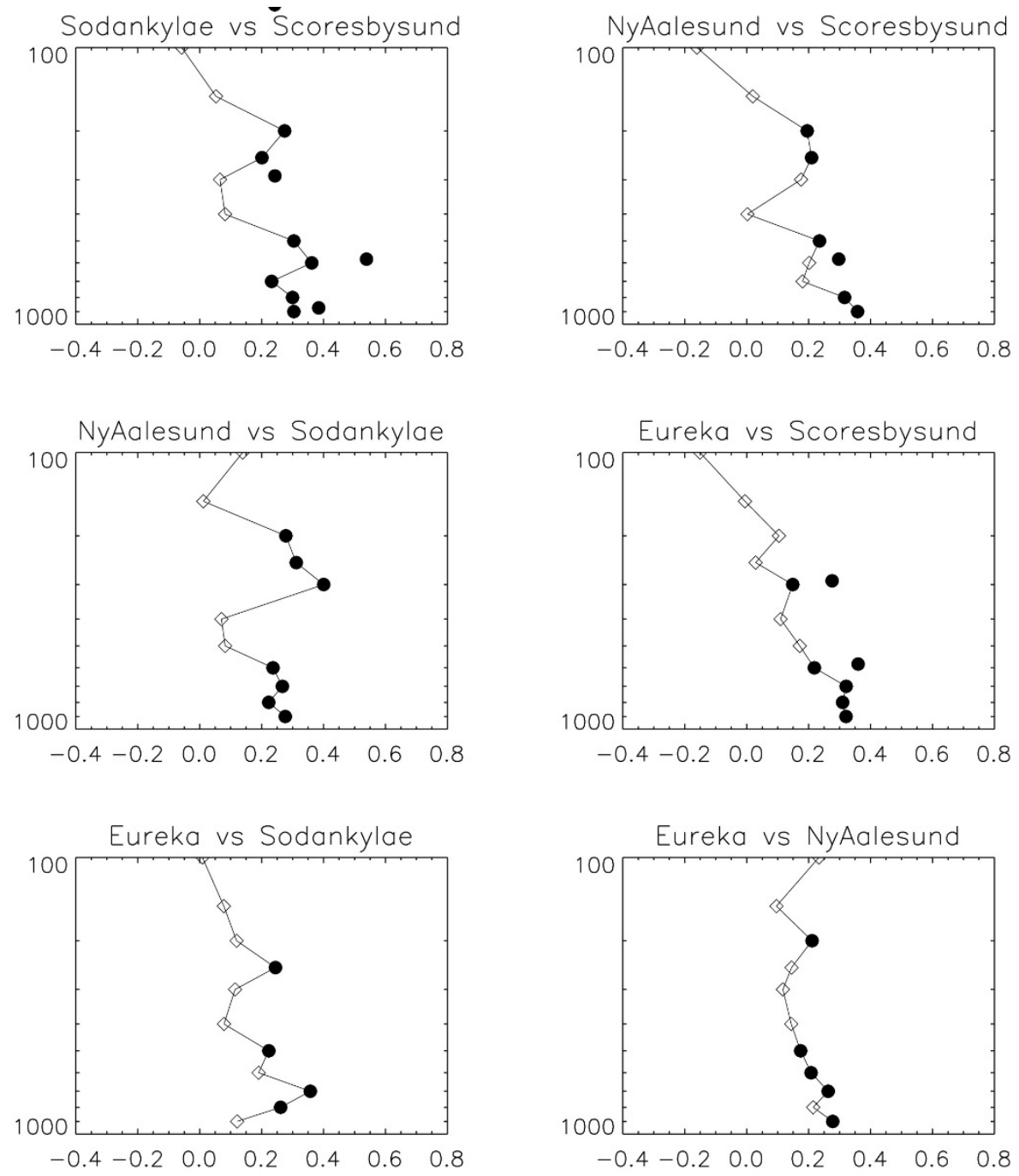

\subsection{Ozone and the Large Scale Circulation}

In this section we will investigate if the ozone anomalies are connected to the large scale circulation. As measures of the large scale circulation we will use the NAO index and the polar front area. Note that the weak correlations between ozone at the different stations discussed in the last section indicate that a connection to the large scale circulation will be weak. 
Figure 12: Correlations between ozone at different vertical layers and the NAO index. Filled symbols indicate significant correlations
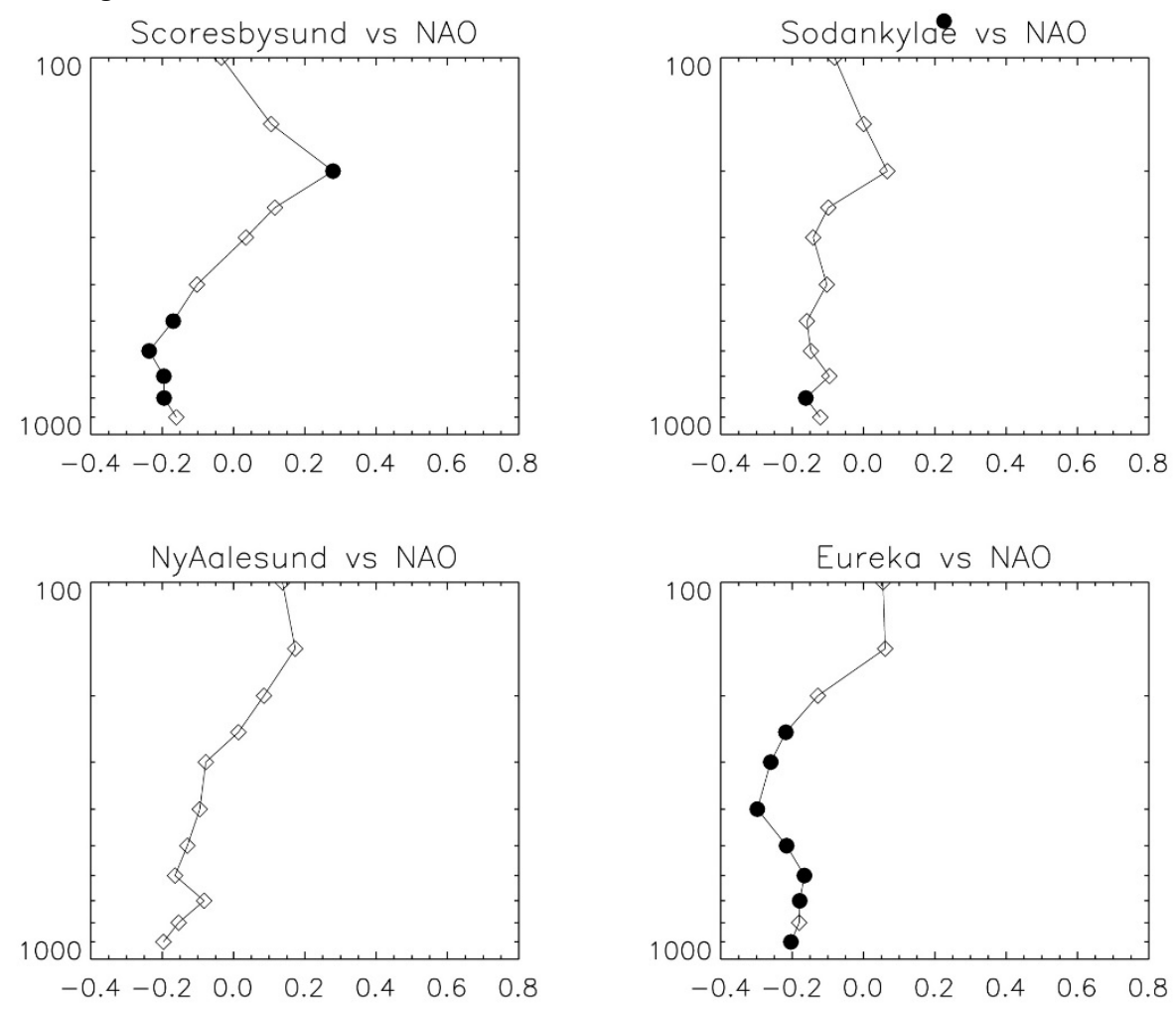

Correlations between ozone in the lowest part of the troposphere and the NAO index are consistently negative for all stations (Figure 12). The values are weak - around -0.2 - and only statistically significant for Scoresbysund and Eureka. Negative correlations of similar magnitude are found at other levels in the lower troposphere.

Correlations between the polar front area and ozone are shown in Figure 13. Here Scoresbysund and Eureka show significant positive values around 0.2 consistent with the positive correlations found for the NAO. Ny Ålesund also shows positive correlations around $\mathbf{0 . 2}$, although they are not significant. Sodankylä shows insignificant weak negative correlations.

The signs of the correlations can be partly understood from dynamical arguments. A weak NAO index indicates a less zonal situation with a tendency for blockings and more transport between the polar region and mid-latitudes. This will enhance the probability of precursors to reach the Arctic and increase the ozone production. The less zonal situation also corresponds to a smaller polar front area. 
Figure 13: Correlations between ozone at different vertical layers and the polar front area. Filled symbols indicate significant correlations
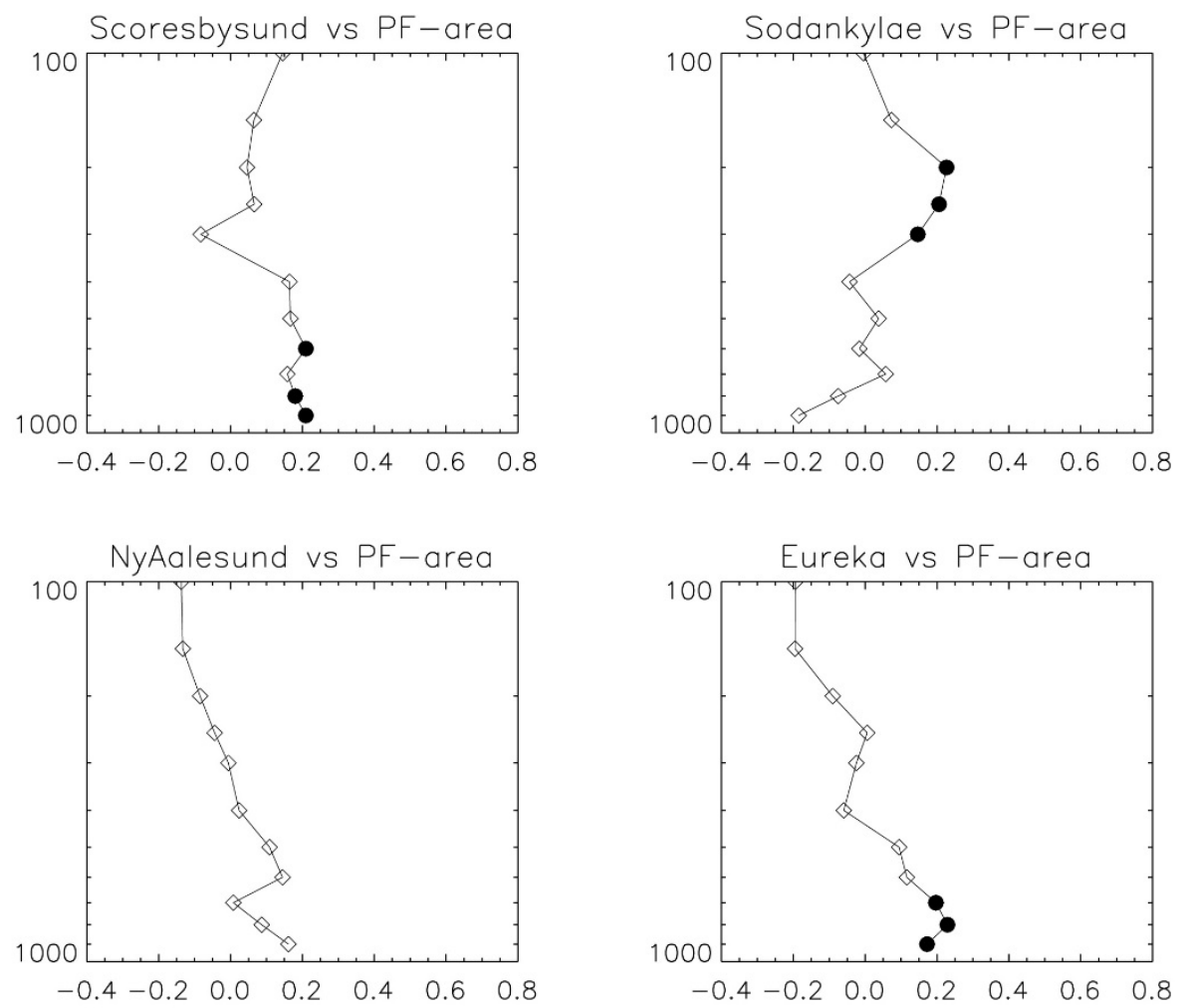

\section{$2.5 \quad$ Robustness}

The main parameter in the calculation is the width used in the kernel smoother. This width determines the amount of smoothing in the ozone timeseries used for calculating the correlations. Note that for consistency we applied the same smoothing to the other time-series - e.g., the NAO and the polar front area. We have confirmed that our results are robust to changes in this parameter: Values between 0.01 and 0.04 (corresponding to smoothing time-scale of approx. 4-16 days) give basically identical results although in general the correlations increase weakly with the size of the smoothing width.

It is also interesting that the amount of autocorrelation in the smoothed time-series seem determined by the width of the kernel smoother indicating that the raw anomalies have small temporal correlation length. This means that the ozone anomalies are basically independent and that the main driver of the anomalies is fast local processes.

In the calculations above we have removed the secular trend and the annual cycle by assuming the trend has the form of a 3 rd order polynomial and that the annual cycle could be expanded in 4 harmonics. We have confirmed that our results are not sensitive, neither to the order of the polynomial or the number of harmonics. 


\section{Conclusions and discussion}

Regarding ozone we have taken as starting point the homogenized ozone series described in our former KOL report "Time Series Analysis of Arctic tropospheric ozone as a short-lived climate forcer" (Christiansen et al., 2015).

- We have calculated the ozone anomalies for four Arctic stations, Scoresbysund, Sodankylä, Ny Ålesund and Eureka, with good data coverage in the period 1993-2011.

- The anomalies have been calculated as the residual after removing a secular trend and an annual cycle.

- To analyze the irregularly sampled anomalies we have interpolated them to daily values using a kernel smoother.

- The resulting ozone anomalies at the lowest level ( $900 \mathrm{hPa}$ ) to some extent represent ozone anomalies in the lowest part of the troposphere.

- There is a weak but significant correlation between tropospheric ozone at the four different stations.

As a possible large scale driver of the Arctic ozone anomalies we have considered the polar front area.

- The polar front defined as the 5,520 m isohypse of the $500 \mathrm{hPa}$ layer is welldefined in winter.

- The polar front area reveals a negative trend which we have argued is due to the general warming of the troposphere/surface system.

- The polar front area correlates strongly and negatively with the NAO.

Regarding the relation between the large-scale dynamics and the ozone anomalies we found:

- The NAO correlates negatively with ozone anomalies for all four stations albeit the correlations are weak.

- The polar front area correlates weakly positive with the ozone anomalies for three out of the four stations.

- These results, together with the observation that the ozone-anomalies have a brief decorrelation time, indicate that most of the variability in the anomalies should be found in local conditions. 
A continuation of this project might include case analysis using back trajectories or CCMVal data (SPARC, 2009), preferably combined with more observation data than was available within this project. 


\section{References}

CCMVal (2009): https://www.pa.op.dlr.de/CCMVal/

Christiansen, B., Jepsen, N., Kiwi, R., Hansen, G.H., Larsen, N. and Korsholm, U. (2015): Time Series Analysis of Arctic tropospheric ozone as a short-lived climate forcer. Nordic Council of Ministers.

Christiansen, B., Jepsen, N., Kiwi, R., Hansen, G.H., Larsen, N. and Korsholm, U. (2017): Trends and Annual Cycles in Soundings of Arctic Tropospheric Ozone . In Preparation.

Chung, M.K. (2012): http://www.pages.stat.wisc.edu/ mchung/teaching/768/reading/lectureo2smoothing.pdf

Harris, N. R. P., Kyrö, E., Staehelin, j.,Brunner, D., Andersen, S.-B., Godin-Beekmann, S., Dhomse, S.,Hadjinicolaou, P.,Hansen, G., Isaksen, I.,Jrrar, A., Karpetchko, A., Kivi, R., Knudsen, B., Krizan, P., Lastovicka, J., Maeder, J.,Orsolini, Y.,Pyle, J. A., Rex, M., Vanicek, K., Weber, M.,Wohltmann, I.,Zanis, P., and Zerefos, C. (2008): Ozone trends at northern mid- and high latitudes - a European perspective, Ann. Geophys., 26, 1-14. https://doi.org/10.5194/angeo-261207-2008

Hastie, T., Tibshirani, R., Friedman, J. (2009): Chapter 6: The Elements of Statistical Learning: Data Mining, Inference and Prediction, Springer. https://doi.org/10.1007/978-0-387-84858-7

Hudson, R.D., Frolov, A.D., Andrade, M.F. and Follette, M.B. (2003): The Total Ozone Field Separated into Meteorological Regimes. Part I: Defining the Regimes, American Meteorological Society, July 2003, vol. 6o, p. 1669-1677. https://doi.org/10.1175/1520-

0469(2003)06o<1669:ttofsi>2.0.c0;2

Jacob, D.J., Fan, S.-M., Wofsy, S.C., Spiro, P.A., Bakwin, P.S., Ritter, J.A., Browell, E.V., Gregory, G.L., Fitzjarrald, D.R., Moore, K.E. (2012): Deposition of ozone to tundra, Journal of Geophysical Research: Atmospheres (1984-2012), Vol. 97, Issue D15, pp. 16473-16479.

Jülich (2012): http://www.fz-juelich.de/iek/iek8/EN/Expertise/Infrastructure/JOSIE/Priciple_node.html

Kivi, R., Bojkov, B., Kyro, E., Heikkinen, P., McGee, T., Brinksma, E. (2008): The Sodankyla Total Ozone Intercomparison and Validation Campaign: ozonesonde observations, 37th COSPAR Scientific Assembly, p. 1534.

Kivi, R., Kyrö, E., Turunen, T., Harris, N. R. P. von der Gathen, P, Rex, M, Andersen, S.B., and Wohltmann, I (2007): Ozonesonde observations in the Arctic during 1989-2003: Ozone variability and trends in the lower stratosphere and free troposphere, J. Geophys. Res., 112, Do8306, https://doi.org/10.1029/2006JDo07271

Larsen, N., Knudsen, B. (1996): Pinatubo aerosols and ozone observed during three winters at Thule by balloonborne backscatter sondes, in G. Fiocco, D Fuà, og G. Visconti (ed.): "The Mt. Pinatubo eruption - Effects on the atmosphere and climate", p.189-198, NATO ASI Series, Subseries I, "Global Environment Change".

Larsen, N., Knudsen, B., Mikkelsen, I.S., Jørgensen, T.S., and Eriksen, P. (1994): Ozone depletion in the arctic stratosphere in early 1993, Geophysical Research Letters, 21, 1611-1614. https://doi.org/10.1029/94GL01394

Law, K., Arnold, S., Langner, J., Korsholm, U. (2015): AMAP Assessment 2015: Black carbon and ozone as Arctic climate forcers, 11-14.

Metoffice (2016): http://www.metoffice.gov.uk/hadobs/hadcrut4/

Metoffice (2016): http://www.metoffice.gov.uk/learning/learn-about-the-weather/howweather-works/global-circulation-patterns 
Pio, C.A., Feliciano, M.S. (1996): Dry Deposition of Ozone and Sulphur Dioxide Over Low Vegetation in Moderate Southern European Weather Conditions. Measurements and Modelling, Phys. Earth, Vol. 21, No. 5-6, pp. 373-377. https://doi.org/10.1016/soo79-1946(97)81126-3

Rasmussen, A., Kiilsholm, S., Sørensen, J.H., Mikkelsen, I.S. (1997): Analysis of tropospheric ozone measurements in Greenland, Tellus (1997), 49B, 510-521.

https://doi.org/10.3402/tellusb.v49i5.15989

Rex, M. (1993): Stratosphärische Ozonabbauraten aus den Ozonsondendaten der EASOEKampagne im Winter 1991/92. Diplom thesis, Georg-August-Universität zu Göttingen.

Smit, H., Oltmans, S., Deshler, T., Tarasick, D., Johnson, B., Schmidlin, F., Stuebi, R., Davies, J. (2012): Past Changes in the Vertical Distribution of Ozone, $\mathrm{O}_{3} S-D Q A$ Activity: Guide Lines for Homogenization of Ozone Sonde Data (Version 2.0: 12. October 2012).

Sørensen, J.H., Nielsen, N.W., (2000): Intrusion of Stratospheric Ozone to the Free Troposphere Through Tropospause Folds - A Case Study, Phys. Chem. Earth (B), Vol. 26, No. 10, pp. 801-806. https://doi.org/10.1016/S1464-1909(01)00088-o

Tarasick, D.W., Fioletov, V.E., Wardle, D.I., Kerr. J.B., Davies. J. (2005): Changes in the vertical distribution of ozone over Canada from ozonesondes: 1980-2001, Journal of Geophysical Research, vol. 110, D02304. https://doi.org/10.1029/2004JDo04643

von der Gathen, P. Rex, M., Harris, N.R.P. Lucic, D. Knudsen, B.M., Braathen, G.O., Backer, H.D., Fabian, R., Fast, H., Gil, M., Kyrö, E., Mikkelsen, I.S., Rummukainen, M. Stähelin, J., Varotsos, C. (1995): Observational evidence for chemical ozone depletion over the Arctic in winter 1991-92, Nature, 375, pp. 131-134. https://doi.org/10.1038/375131ao

Wespes, C. Emmons, L. Edwards, D. P. Hannigan, J. Hurtmans, D. Saunois, M. Coheur, P. -F. Clerbaux, C. Coffey, M. T. Batchelor, R. L. Lindenmaier, R. Strong, K. Weinheimer, A. J. Nowak, J. B. Ryerson, T. B. Crounse, J. D. Wennberg, P. O. (2012): Analysis of ozone and nitric acid in spring and summer Arctic pollution using aircraft, ground-based, satellite observations and MOZART-4 model: source attribution and partitioning. Atmospheric Chemistry and Physics, 12 (1). pp. 237-259. https://doi.org/10.5194/acp-12-237-2012 


\section{Sammenfatning}

En forøget aktivitet kan forventes i Arktis i den nærmeste fremtid, med bidrag fra en forøget fragtsejlads og en forøget eftersøgning efter undersøiske forekomster af især olie og gas. Til lands må - ikke mindst i Grønland - forventes en forøget aktivitet ved eftersøgning efter industrimineraler. Disse aktiviteter vil føre til en større afbrænding af fossile brændsler og dermed også en forøget forekomst af kortlivede klimakomponenter. En forøget forekomst, der kun kan reguleres politisk.

Èn af disse klimakomponenter er troposfærisk ozon, eftersom det kan dannes som et biprodukt ved afbrænding af fossile brændsler. I modsætning til stratosfærisk ozon (det såkaldte ozonlag, se nedenfor), er troposfærisk ozone en uønsket bestanddel. Der findes et antal årsager herfor: Selv om troposfærisk ozon - ligesom stratosfærisk ozon - absorberer især den kortbølgede del af den ultraviolette stråling, har den også et antal giftige bevirkninger grundet dens meget reaktive beskaffenhed. Som sådan kan den påvirke levende væv, såsom lungerne hos pattedyr, men også respiratorisk plantevæv.

De troposfæriske ozondata, der er anvendt i denne undersøgelse, kan opfattes som "biprodukt" ved ozonsonderingerne. Disse målinger blev oprindeligt påbegyndt som en undersøgelse af den stratosfæriske ozon som en opfyldelse af Montreal Protokollen til monitering af ozonlaget. I denne henseende refererer udtrykket "ozonlag" alltid til stratosfærisk ozone, dvs. ozon i atmosfæren i 25-40 km's højde. Disse målinger begyndte sidst i 1980erne eller de tidligere 199oere for de fleste stationers vedkommende. Ozonsonderingen i sig selv udføres ved at løfte sondeudstyret med en ballon, indtil den sprænger, sædvanligvis i omkring 35 km's højde. Målingen af ozon udføres kun under opstigningen.

Så selv om hovedformålet med ozonsonderingerne var undersøgelsen af stratosfæren, kan de samme data nu anvendes til at etablere en basislinie for den troposfæriske ozon, som den har set ud de seneste 30 år. Og forhåbentlig vil dataserien fortsætte med at vokse i de kommende år, så vi stadig er i stand til at monitere og detektere ændringer af ozonkocentrationerne i stratosfæren såvel som i troposfæren.

One of these climate components is trophospheric ozone because it may be formed as a byproduct when combusting fossile fuels. In contrast to stratospheric ozone that is protecting the earth against ultraviolet radiation, tropospheric ozone is an unwanted constituent. There are a number of reasons for this. Although tropospheric ozone - like the stratospheric ozone - absorbs ultraviolet radiation, it also has a number of poisoneous side effects due to its very reactive nature. In this respect it may affect living tissue, such as the lungs in mammals, and also respiratory plant tissue.

Mængden af troposfærisk ozon på et givet sted antages at være reguleret på tre måder: ved lokal dannelse af forstadiematerialer, ved tilførsel af forstadiematerialer fra andre lokationer og ved foldning af stratosfæren ned i troposfæren. Forstadiematerialerne kan vanset om de er dannet lokalt eller tilført udefra - reagere og danne troposfærisk ozon. 
Foldning af stratosfæren vil injicere ozon direkte ind i den øvre troposfære. Fra en politikers synspunkt kan alene lokalt dannede og tilførte forstadiematerialer reguleres. Forstadier til ozon skyldes menneskelig aktivitet, såsom afbrænding af brændsel, såvel som fra naturlige kilder, såsom skovbrande. Stratosfærefoldning er en proces, der er iboende den dynamiske atmosfære.

Som en del af dette project har vi undersøgt forbindelsen mellem polarfronten og den arktiske troposfæriske ozon. Polarfronten er en afgrænsning rundt om Nordpolen, der adskiller varme luftmasser sydfra, fra koldere luftmasser i det polare område.

Det viste sig, at arealet af polarfronten udviser en aftagende tendens over tid, muligvis på grund af den generelle opvarmning af troposfæren.

Et andet emne i undersøgelsen er forbindelsen mellem polarfronten og indekser for storskalacirkulationen, såsom den Nordatlantiske oscillation (NAO). Det viste sig, at arelaet af polarfronten korrelerer stærkt og negativt med NAO.

Ved at anvende de homogeniserede ozonsondedataserier fra den tidligere KOLrapport (Christiansen et al., 2015) er anomalierne blevet beregnet som residualet efter fjernelse af den lavfrekvente tendens og den årlige cyklus. Ved anvendelse af en "kernel smoother" (Hastie et al., 2009) er anomalierne blevet interpoleret til gennemsnitlige daglige værdier.

På denne måde blev der fundet en svag, men signifikant korrelation mellem de udvalgte stationer.

Det viste sig også, at NAO'en korrelerer negativt med ozonanomalierne for alle fire stationer, selv om korrelationerne er svage.

Disse resultater antyder, sammen med den iagttagelse at ozonanomalierne har en kort dekorrelationstid, at det meste af variabiliteten i anomalierne skal findes i lokale betingelser. 
Nordic Council of Ministers

Nordens Hus

Ved Stranden 18

DK-1061 Copenhagen K

www.norden.org

\section{Air Quality in the Nordic Countries and Climate Changes in the Arctic}

The report use ozone measurement data retrieved in the Arctic with balloon borne ozone sondes for the last 20-30 years. Four stations with the best data series have been selected. Using a Monte Carlo method the yearly period is subtracted from the data and the remains, the anomalies, are correlated towards the area of the Polar Front, the temperature rise of the Nortern Hemisphere and the North Atlantic Oscillation (NAO) and towards one another. It was found that the NAO correlates negatively with ozone anomalies for all four stations albeit the correlations are weak. Besides, the polar front area correlates weakly positive with the ozone anomalies for three out of the four stations. These results, together with the observation that the ozone-anomalies have a brief decorrelation time, indicate that most of the variability in the anomalies should be found in local conditions. 